intensive mackerel fishing and the large amount of sport fishing, has resulted in an increase of 950 boats in 1840-41 registrations over the previous year and is most noticeable in the group between $25 \mathrm{ft}$. and $39 \mathrm{ft}$. long. There has been a steady development of sport fishing in the ocean waters of Southern California, and the amount of small fish required as bait must be considered together with its effect on the severel species used as bait. The statistical records include not only the sport catoh itself but also the harvesting of the small-sized fishes used by the anglers for bait. Sardines and anchovies are the most important in the bait catch, comprising 98 per cent of the tatal, the fishes being $2 \frac{1}{2}-6$ in. long. A useful list of the common and scientific names of fishes, crustaceans and molluscs involved in the fisheries is given at the end of the report.

\section{Inter-American Friendship through the Schools}

THE U.S. Office of Education has issued as Bulletin No, 10, 1941, "Inter-American Friendship through the Schools", a report based upon a research study conducted by the Office of Education for the specific purpose of ascertaining the extent of inter-American studies that are already a part of the school curriculum. The bulletin is based largely on the replies of school administrators to a questionnaire, and the central purpose of the investigation was to discover the opportunities of learning which the curriculum presents and the patterns of teaching relative to the development of inter-American understanding that are to be found in the elementary and secondary schools of the United States. From the 6,623 adIministretors to whom the questionnaire was sent, 2,4.71 replies were received in time to be tabulated for the report, Of these, 671 stated that Spanish was being taught, and one half of the sehools reporting indicated that, although they did not offer Spanish, they provided a study of the other Americas in various courses given in English. No study relating to the other American republics in Spanish or in English was reported by $\mathbf{5 2 1}$ of the schools.

\section{Dinosaur Find at Washington, D.C.}

IT is stated by Science Service, of Washington, D.C., that the broken upper part of a saurian thigh. bone has been found in a new excavation being made for the D.C. filtration plant at Washington. The bone was identified as belonging to one of the sauropod group of dinosaurs by Dr. C. W. Cilmore, curator of vertebrate palæontology at the U.S. National Museum. Two finds of dinosaur bones have previously been made in Washington; they were of rather fragmentary fossils. Judging from the sixe of the present find, Dr. Gilmore said, the original animal was about ten feet high at the hips and fifty or sixty feet long, weighing approximately ten tons. Apparently, from the geological evidence, it was trapped in a small pond or mudhole and so perished. These creatures lived during the Cretaceous, about 150 million years ago.

\section{Restoration of Historic Monuments in the U.S.S.R.}

A sPECral committeo for the registration and protection of architectural relics and historic monuments has been set up by the Soviet Government. It consists of leading members of the Academy of Sciences and arehitects, headed by Igor Grabar, a Stalin prize- winner. One duty of this committee will be to establish the amount and nature of the deatruction and damage caused by the Germans in occupied districts and, where restoration is at all possible, to supervise the work.

\section{Cosmic Ray Research}

AN expedition of the Academy of Sciences of the U.S.S.R., led by Prof. A. I. Alikhanov, has arrived in Erevan, the capital of Soviet Armenia, to study cosmic rays. It will be in the field for about six weeks, making observations at the high-altitude meteorological station in the Alpaz mountains.

\section{Recent Earthquakes}

A SEVERE earthquake shook the towns of Santiago and Valparaiso and the region between the towns at about 1.30 a.m. (local time) on June 29. The Intendencia, headquarters of the Provincial Government, and other buildings were damaged in Valparaiso. Property was also damaged in Santiago, and for a while the electricity supply was interrupted. Thirty-seven people were reported injured. The earthquake was probably the most severe in Chile since 1927, when Talca and Concepcion were destroyed.

A moderate earthquake shook the town of Karachi at 8.30 a.m. approximately on the morning of July 3. No damage has been reported.

\section{Free German Institute in London}

A Free German Institute is being founded by the science section of the Free German I League of Culture in Great Britain. The airns of the Institute are : (i) to uphold and develop the valuable traditions of the Free German research work and teaching ; (ii) to provide for interchange of opinion between Free German men of science and those of the United Nations; (iii) to strengthen the German refugee youth in the spirit of intermational understanding, and to enable them to help in re-shaping Germany's cultural life after the destruction of Nazism. The opening session will be held on July 17 at 7.30 p.m. at the Everyman Theatre, when an address will be given by Dr. Joseph Needham. Further particulars of the movement can be obtained from the secretary, Free German League of Culture, 36 Upper Park Road, London, N.W.3.

\section{Announcements}

The honorary degree of D.Litt of the University of Oxford has been conferred on Commander Claude Schaeffer, of the Free French Navy, who is deputy curator of the Musée des Antiquités Nationales at Saint-Germain, and conducted important archæological excavations at Ras Shamra in North Syria.

A WhOLE-DAY conference is being arranged by the Nutrition Society, jointly with the Food Group of the Society of Chemical Industry, on "Dehydration of Foods and the Effect on their Nutritional Value", to be held at the British Medical Association House, London, on July 25. A later meeting, probably at the end of October, will deal with "Trace Elements in Nutrition". Further particulars of meetings can be had from the honorary secretary of the Nutrition Society, Dr. Leslie Harris, Nutritional Laboratory, Milton Road, Cambridge. 